\title{
Ethnobotanical Study of the Rural Population of the West of the Pampa Plain (Argentina)
}

\author{
Walter Alejandro Muiño
}

\section{Research}

\begin{abstract}
This paper is an ethnobotanical study of cattle farming in the western Pampa region of Argentina, an arid region with very scarce rainfall and a population consisting mainly of Criollo farmers. A total of 68 rural settlers were interviewed, providing information on 69 specific and infraspecific taxa. Plants were classified into the following categories according to use: forage, toxic species or species with adverse effects on animals, use in rural constructions, tools, and those with veterinary applications. Data include native, naturalized and cultivated species. They revealed a diverse group of forage plants, according to the type of livestock, and very few toxic plants. Veterinary applications were related to first aid cases. In rural construction, plants were mostly used for fencing paddocks and corrals. The results of this study show the acute level of perception and detailed knowledge of the plant environment held by this farming community in relation to their main economic activity.
\end{abstract}

\section{Introduction}

Livestock farming in arid and semiarid areas is of scientific and technical interest due to the fragility of these ecosystems (Borrelli \& Oliva 2001, Montes \& Oliva 1995, Ojeda et al. 1998). In Argentina, the studies made into this topic aim to describe the environment and the living organisms that compose it (Anderson et al. 1970, Boelcke 1957, Cano 1988), as well as the management guidelines that should be followed for sustainable development of the land (Golluscio et al. 1998, Grünwaldt et al. 1992, Guevara et al. 1996).

Although various ethnobotanical studies on animal farming communities in Patagonia have been made (Ladio \& Lozada 2004, 2008), none of them looks specifically at stock breeding in the Pampa region. Among the stud- ies that address this topic from an anthropological point of view, in Argentina we can mention the work of Jiménez de Pupareli (1984), and other interesting studies on specific issues such as veterinary practices (Bartolomé 1968, Torres \& Santoni 2003). From an ethnobotanical perspective, the works of Scarpa $(2000,2007)$ on veterinary aspects and the management of foraging species in farming communities of the semiarid Chaco are also important.

Current farming development programs are based on incomplete information about the relationship that exists between the rural inhabitant and his natural environment. Ignorance of the cultural framework in each production area is partly responsible for the problems that arise between rural producers and agronomists (Feito 2004). In addition, the Pampa region has areas with different types of vegetation, and its population is of different origins and the result of several colonization processes, each with its own specific sociocultural traits and each one deserving to be explored in studies which relate biology with an-

\section{Correspondence}

Walter Alejandro Muiño, Universidad Nacional de La Pampa. Facultad de Ciencias Exactas y Naturales. Ruta Nac. 35, km. 334 (6300) Santa Rosa, La Pampa. ARGENTINA.

muinio@exactas.unlpam.edu.ar

Ethnobotany Research \& Applications 8:219-231 (2010)

Published: July 31, 2010 
thropology. Likewise, it has been proposed that as more information is gathered on the perception and significance of the environment for native communities, the communication between them and the parties responsible for local development policies will improve (Bollig \& Schulte 1999).

As a result of the above, and due to the constant loss of cultural and natural diversity in a rapidly changing globalized world, the study of animal farming from an ethnobotanical point of view, i.e., taking into account the sociocultural interactions between man and environment, is becoming increasingly important.

As hypotheses it is put forward that farmers from marginal areas of the Pampa plain maintain their traditional knowledge and continue to use natural resources despite the availability of commercial supplies and materials. The aim of this paper is to make an ethnobotanical characterization of animal farming in a community of the northwest of the province of La Pampa. Special emphasis is placed on foraging species, species with toxic or other negative effects for the animals, species for veterinary uses and species used in the creation of facilities and tools for herd management. It is part of a more extensive investigation that includes other ethnobotanical values in the region (Muiño unpublished data).

\section{Study area}

The study area is located in the western half of the Chicalcó department, in the northwest of the province of La Pampa, Argentina, and borders on the province of Mendoza. (Figure 1)

The altitude of the region ranges between 800 and 1,000 m.a.s.l. The soil is loose and sandy, with a sand fraction of $85 \%$ (INTA, Gob. de La Pampa UNLPam 1980). It has occasional calcareous tuff horizons, and in the southwest there are various basaltic horizons emerging from the ancient mantle (Cuello 1968). The northwest section is the highest area and is characterized by a hilly landscape. There are numerous salt pans in the lower-lying areas. Here the landscape is a plain that slopes $0.5 \%$ from west to east, although this value increases in the hilly northwestern area. The historical mean annual rainfall of the area is $200 \mathrm{~mm}$, falling mainly between the months of October to March. However, the last decades have seen a

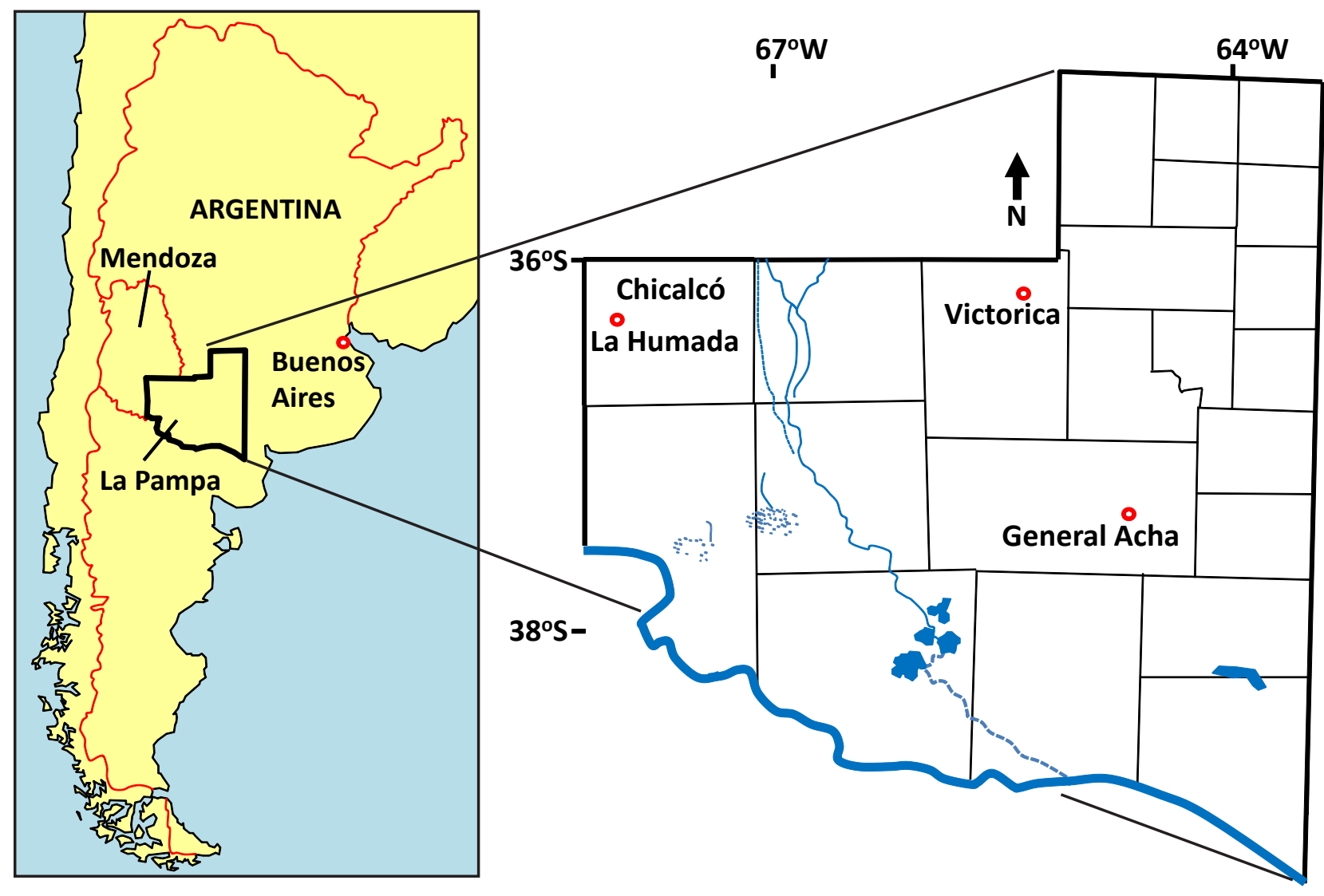

Figure 1. The study area in the western half of Chicalcó department, in the northwest of the province of La Pampa, Argentina, and borders on the province of Mendoza. Towns and provinces where livestock production is sold are also shown. 


\section{Muiño - Ethnobotanical Study of the Rural Population of the West of the Pampa Plain (Argentina)}

shift in isohyets and the region now has annual rainfall of over 300 mm. (Casagrande et al. 2006). Snow can occasionally fall in winter. The mean annual temperature is 14 ${ }^{\circ} \mathrm{C}$ with absolute maximum temperatures of $42{ }^{\circ} \mathrm{C}$ in January and minimum temperatures of $-15^{\circ} \mathrm{C}$ in June (INTA, Gob. de La Pampa, UNLPam 1980).

Most of the area belongs to the Monte phytogeographic province (Cabrera 1971), although the southern sector includes parts of the Payunia province (Martínez Carretero 2004). Vegetation is mainly represented by low open scrubland where Larrea divaricata Cav. is the dominant species together with Junellia seriphioides (Gillies \& Hook.) Moldenke, Acantholippia seriphioides (A. Gray) Moldenke, Poa lanuginosa Poir., Aristida mendocina Phil. and Panicum urvilleanum Kunth. Some areas are also covered by open xerophytic shrublands and halophytic vegetation.

The department of Chicalcó has a surface area of approximately $9,117 \mathrm{~km}^{2}$, and a population of 1,595 inhabitants, with a density of 0.2 inhabitants $/ \mathrm{km}^{2}$. The most important demographic center in the area is the locality of La Humada with a population of 419 inhabitants (INDEC 2001). Due to the presence of springs, there are another two settlements with microclimates that have favoured the concentration of several rural estates. These are the localities of Chos Malal and Agua de Torres, located to the north and south of La Humada respectively.

\section{Stock breeding in the West Pampa region}

The main economic activity of the rural inhabitants of the western Pampa is extensive stock breeding on natural grasslands. After colonization of the region at the end of the $19^{\text {th }}$ century, sheep farming predominated in the area with some bovine farming on a much smaller scale. However, over the years this relationship changed and was actually reversed towards the end of the $20^{\text {th }}$ century (Cuello \& Montone 1999).

Together with this change there was a gradual increase in goat farming, which is now more important than cattle farming in the lower socioeconomic puestos. Puesto is the local word for a domestic unit comprising a rural home and its peridomestic area (Poduje 2000).

Water supply for animal farming is a crucial issue in this region of scarce rainfall. Today all farms have water pump systems based on windmills, internal combustion engines, or both. On some farms wells have been dug down to the water table and are called jagüeles. In these cases, water is extracted using leather balls or buckets and these systems are used exclusively for small herds or to supplement windmills in the event of breakdowns. The balls are made by tying several goatskins together with leather cords, with the hair facing inwards, to produce a round receptacle that varies in capacity. As a general norm each farm is supplied by only one water well and an additional one is generally added when the surface area is larger than 5,000 hectares.

Water is stored in metal tanks whose size varies from corral to corral. Most camps have only one water supply site, which limits their grazing area.

During prolonged droughts, farmers move their animals to other farms under rental contracts, or sell part of their herds to reduce their animal load. Nevertheless, local farmers noticeably tend to keep the animals on their farms for as long as possible and to be over-confident as to the capacity of the farm to recover by resorting to the seed bank when conditions of normal rainfall return. When this fails to happen, serious degradation of the environment results.

According to agronomic estimates, the natural grasslands of this region are able to support a livestock load of one bovine unit every 10 to 35 hectares. (INTA, Gob. de La Pampa, UNLPam 1980).

The puesteros, as the farmers call themselves, have not adopted the transhumance practices which are common in other Monte areas (Ladio \& Lozada 2004, 2008). They manage their herds in a sedentary fashion, just as when the area was colonized; in other words, they leave their animals to graze freely in open grasslands, according to availability and their forage requirements. Furthermore, they do not carry out special grassland management practices such as growing natural or exotic grasses, using enclosures to protect foraging areas, or harvesting and storing forage, as in other stock breeding areas of Argentina (Scarpa 2007), but they do use practices like selective burning to promote resprouting of certain species in order to increase their foraging quality, a common custom in many grazing systems worldwide.

Over the last two decades the number of farms with perimeter fencing has increased, but only very few are divided internally into plots. The size of the farms varies: medium sized farms predominate, while large estates are scarce. The surface area ranges from 2,500 to 5,000 hectares. Smallholdings are rare and are usually exploited by farmers acting as land occupants.

Cattle are enclosed only on special occasions, e.g., to perform vaccinations, pregnancy diagnoses, castrations and other controls. On rare occasions herds of different proprietors can get mixed up, but this does not lead to conflict in the community. Goats on the other hand are enclosed in corrals at night and are then released to graze in the morning. Neighboring puesteros establish mutual agreements for releasing their flocks in different directions to avoid confusion.

There are different forms of land ownership in the area. In some cases, the farmers own the land, while in others they 
are permanent employees with or without the presence of the farm owners. There is also a marked presence of land occupants, whose future is uncertain due to the eviction threats made by the heirs of the original proprietors, or to the arrival of new investors lured by the increasing price of land. This situation is a result of the expansion of the agricultural frontier and the pressure generated on the land market (Gras \& Barbetta 2004).

\section{Types of livestock}

Cattle and goats are the predominant types of livestock, followed in order of importance by sheep and horses. In addition, most households complement their family food requirements by breeding poultry. The main cattle breed in the western Pampa is Aberdeen Angus, which coexists with other strains produced by crossing European and Criollo breeds.

Goat breeding shares the same level of importance as cattle breeding and is greatly favored by the scrubland vegetation of the area. The animals are primarily intended to satisfy the food requirements of the family group, but are also sold for meat in urban centers (see Figure 1). The category with the greatest demand in the market is the cabrito, a one- or two-month-old animal that has yet to be weaned. The dominant caprine breed is commonly known as criollo. It originated from the flocks brought by Spanish colonizers and has fully adapted to the region. It has thus been suggested that the animal be identified as a "regional caprine" (Zuluaga 1973).

Horses are also important in the area, but the number of animals per rural establishment decreased over the second half of the $20^{\text {th }}$ century (INTA, Gob. de La Pampa, UNLPam, 1980).

\section{Methods}

Between 2005 and 2007, seven field trips were made at different times of the year to La Humada, the most important population in the department, and to its surrounding rural area.

Traditional methodology used in social and ethnographical studies was applied in conducting these surveys (Barroso 2000, Guber 2001, Martin 2001). Data were record- ed by participative observation, or by open and semistructured interviews. These methods allow a great deal of base information to be obtained, especially when no previous documentation exists about a community, as in this case. At the same time they have the disadvantage of making difficult the attainment of standardized responses for further quantitative analysis. All records were written, with one exception in which it was deemed more convenient to make a recording on magnetic tape. Interviews were organized in thematic units, i.e., forages for different animals, plants with toxic and negative effects, plants for veterinary use, and species used in rural construction.

Field trips were organized to allow the interviewees to identify the plants with their common name, and they were asked to describe their uses and local significance. Samples of the specimens mentioned were collected after the interviews and any additional information was recorded. When the age or health of the informant did not allow this, fresh samples were collected and taken to their home for interviewees to identify and provide the required information. Samples were simultaneously collected to prepare herbarium specimens.

A total of 68 individuals ( 27 women and 41 men) between 24 and 86 years old were interviewed. The mean age of the population was 56 . The information was recorded on a database to facilitate subsequent analyses; species were arranged according to their scientific and common name and categories of use together with the informant's data.

All collected samples were processed into herbarium voucher specimens. These were identified taxonomically by the author, except in cases requiring the collaboration of specialists from the Faculty of Agronomy of the Universidad Nacional de La Pampa. The specimens are stored at the herbarium of Universidad Nacional de La Pampa Argentina, La Pampa, Santa Rosa (SRFA).

\section{Results}

\section{Forage resources}

A total of 52 foraging plants were identified, with different animal preferences according to the type of livestock (Table 1). The winter grass cited most was unquillo ( $P$. lanuginosa). Also of importance were the following grass-

Table 1. Foraging species for all types of livestock based on the perception of interviewees (number of quotes) in the western half of Chicalcó department, in the northwest of the province of La Pampa, Argentina. Foraging importance is expressed as IF = Is/N where I is the number of times the species $\mathrm{s}$ was cited and $\mathrm{N}$ is the total number of events or interviews.

\begin{tabular}{|c|l|l|l|l|}
\hline $\begin{array}{c}\text { Number } \\
\text { of quotes }\end{array}$ & IF & Species & $\begin{array}{l}\text { Common } \\
\text { name }\end{array}$ & $\begin{array}{l}\text { Collection } \\
\text { number }\end{array}$ \\
\hline 41 & 0.60 & Panicum urvilleanum Kunth. (Poaceae) & Tupe & $\begin{array}{l}\text { Muiño \& } \\
\text { Arenas 35 }\end{array}$ \\
\hline 39 & 0.57 & Poa lanuginosa Poir. (Poaceae) & Unquillo & Muiño 160 \\
\hline
\end{tabular}




\section{Muiño - Ethnobotanical Study of the Rural Population of the West of the Pampa Plain (Argentina)}

\begin{tabular}{|c|c|c|c|c|}
\hline $\begin{array}{l}\text { Number } \\
\text { of quotes }\end{array}$ & IF & Species & $\begin{array}{l}\text { Common } \\
\text { name }\end{array}$ & \begin{tabular}{|l|}
$\begin{array}{l}\text { Collection } \\
\text { number }\end{array}$ \\
\end{tabular} \\
\hline 29 & 0.43 & Schinus johnstonii F.A.Barkley (Anacardiaceae) & Molle & Muiño 88 \\
\hline 27 & 0.40 & Lycium chilense Miers ex Bertero (Solanaceae) & Llaullín & Muiño 47 \\
\hline 21 & 0.38 & Prosopis flexuosa DC. var. depressa F.A. Roig (Fabaceae) & Alpataco & Muiño 102 \\
\hline 20 & 0.29 & Condalia microphylla Cav. (Rhamnaceae) & Piquillín & Muiño 13 \\
\hline 17 & 0.25 & Pappostipa vaginata (Phil.) Romasch. (Poaceae) & Coirón & \\
\hline 14 & 0.21 & Acantholippia seriphioides (A.Gray) Moldenke (Verbenaceae) & Tomillo & Muiño 119 \\
\hline 14 & 0.21 & Aristida mendocina Phil. (Poaceae) & Flechilla & Muiño 4 \\
\hline 13 & 0.19 & $\begin{array}{l}\text { Bromus catharticus Vahl var. rupestris (Speg.) Planchuelo \& } \\
\text { P.M. Peterson (Poaceae) }\end{array}$ & Cebadilla & Muiño 121 \\
\hline 13 & 0.19 & Nassella tenuis (Phil.) Barkworth (Poaceae) & Flechilla fina & Muiño 151 \\
\hline 10 & 0.15 & Ephedra ochreata Miers (Ephedraceae) & Solupe frutero & Muiño 90 \\
\hline 10 & 0.15 & Larrea divaricata Cav.(Zygophyllaceae) & Jarilla & $\begin{array}{l}\text { Muiño \& } \\
\text { Arenas } 38\end{array}$ \\
\hline 8 & 0.12 & Atriplex lampa (Moq.) Gillies ex Small (Amaranthaceae) & Zampa & Muiño 106 \\
\hline 8 & 0.12 & Monttea aphylla (Miers) Benth. \& Hook. f. (Plantaginaceae) & Ala & Muiño 52 \\
\hline 7 & 0.10 & Schismus barbatus (L.) Thell. (Poaceae) & $\begin{array}{l}\text { Pasto de } \\
\text { invierno }\end{array}$ & Muiño 117 \\
\hline 7 & 0.10 & Thelesperma megapotamicum (Spreng.) Kuntze (Asteraceae) & Té pampa & Muiño 22 \\
\hline 6 & 0.09 & Hyalis argentea D. Don ex Hook. \& Arn. (Asteraceae) & Blanquilla & Muiño 79 \\
\hline 5 & 0.07 & Grindelia chiloensis (Cornel.) Cabrera (Asteraceae) & Melosa & Muiño 73 \\
\hline 5 & 0.07 & $\begin{array}{l}\text { Prosopidastrum striatum (Benth.) R. A. Palacios \& Hoc } \\
\text { (Fabaceae) }\end{array}$ & Retamilla & $\begin{array}{l}\text { Muiño \& } \\
\text { Arenas } 26\end{array}$ \\
\hline 4 & 0.06 & Baccharis gilliesii A. Gray (Asteraceae) & Yerba de oveja & Muiño 171 \\
\hline 4 & 0.06 & Bothriochloa springfieldii (Gould) Parodi (Poaceae) & Pasto de hoja & Muiño 129 \\
\hline 4 & 0.06 & Gomphrena mendocina (Phil.) R.E. Fr. (Amaranthaceae) & Yerba del pollo & $\begin{array}{l}\text { Muiño \& } \\
\text { Arenas } 24\end{array}$ \\
\hline 4 & 0.06 & Jarava ichu Ruíz \& Pav. (Poaceae) & Coirón fino & Muiño 66 \\
\hline 3 & 0.04 & Chuquiraga erinacea D. Don (Asteraceae) & Chirriadora & Muiño 39 \\
\hline 3 & 0.04 & $\begin{array}{l}\text { Junellia seriphioides (Gillies \& Hook. ex Hook.) Moldenke } \\
\text { (Verbenaceae) }\end{array}$ & Tomillo macho & Muiño 33 \\
\hline 3 & 0.04 & Parthenium hysterophorus L. (Asteraceae) & Altamisa & Muiño 99 \\
\hline 3 & 0.04 & Senna aphylla (Cav.) H.S. Irwin \& Barneby (Fabaceae) & $\begin{array}{l}\text { Cacho de } \\
\text { cabra }\end{array}$ & $\begin{array}{l}\text { Muiño \& } \\
\text { Arenas } 36\end{array}$ \\
\hline 3 & 0.04 & Setaria mendocina Phil. (Poaceae) & Pasto de hoja & Muiño 5 \\
\hline 2 & 0.03 & $\begin{array}{l}\text { Eragrostis mexicana (Hornem.) Link ssp. virescens (J. Presl.) } \\
\text { S.D. Koch \& Sanchéz Vega (Poaceae) }\end{array}$ & Gramilla & Muiño 127 \\
\hline 2 & 0.03 & Bougainvillea spinosa (Cav.) Heimerl (Nyctaginaceae) & Monte negro & Muiño 98 \\
\hline 2 & 0.03 & $\begin{array}{l}\text { Eupatorium patens D. Don ex Hook. \& Arn. var. patens } \\
\text { (Asteraceae) }\end{array}$ & Bejuco & Muiño 44 \\
\hline 2 & 0.03 & Fabiana peckii Niederl. (Solanaceae) & Pichanilla & $\begin{array}{l}\text { Muiño \& } \\
\text { Arenas } 31\end{array}$ \\
\hline 2 & 0.03 & $\begin{array}{l}\text { Glandularia flava (Gillies ex Hook.) Schnack \& Covas } \\
\text { (Verbenaceae) }\end{array}$ & $\begin{array}{l}\text { Yerba de } \\
\text { la vaca }\end{array}$ & Muiño 14 \\
\hline
\end{tabular}




\begin{tabular}{|c|l|l|l|l|}
\hline $\begin{array}{c}\text { Number } \\
\text { of quotes }\end{array}$ & IF & Species & $\begin{array}{l}\text { Common } \\
\text { name }\end{array}$ & $\begin{array}{l}\text { Collection } \\
\text { number }\end{array}$ \\
\hline 2 & 0.03 & $\begin{array}{l}\text { Gochnatia glutinosa (D. Don) D. Don ex Hook. \& Arn. } \\
\text { (Asteraceae) }\end{array}$ & Jarillilla & Muiño 10 \\
\hline 2 & 0.03 & Neosparton aphyllum (Gillies \& Hook.) Kuntze (Verbenaceae) & Solupe & Muiño 114 \\
\hline 2 & 0.03 & Pappophorum philippianum Parodi (Poaceae) & Pasto de hoja & Muiño 140 \\
\hline 2 & 0.03 & Plantago patagonica Jacq. (Plantaginaceae) & Cola de piche & Muiño 108 \\
\hline 2 & 0.03 & Ximenia americana L. (Olacaceae) & Albaricoque & Muiño 163 \\
\hline 1 & 0.01 & Baccharis salicifolia (Ruiz \& Pav.) Pers. (Asteraceae) & Chilca & Muiño 30 \\
\hline 1 & 0.01 & Caesalpinia gilliesii (Wall ex Hook.) D. Dietr. (Fabaceae) & Mal de ojo & Muiño 164 \\
\hline 1 & 0.01 & Erodium cicutarium (L.) L'Hér. ex Aiton (Geraniaceae) & Alfilerillo & Muiño 71 \\
\hline 1 & 0.01 & Jarava neaei (Nees ex Steud.) Peñailillo (Poaceae) & Flechilla & Muiño 2 \\
\hline 1 & 0.01 & Junellia aspera (Gillies \& Hook.) Moldenke (Verbenaceae) & Monte negro & $\begin{array}{l}\text { Steibel } \\
2512\end{array}$ \\
\hline 1 & 0.01 & Larrea cuneifolia Cav. (Zygophyllaceae) & Jarilla crespa & Muiño 149 \\
\hline 1 & 0.01 & Lycium gilliesianum Miers (Solanaceae) & Llaullín crespo & Muiño 85 \\
\hline 1 & 0.01 & Margyricarpus pinnatus (Lam.) Kuntze (Rosaceae) & $\begin{array}{l}\text { Yerba de } \\
\text { la perdiz }\end{array}$ & $\begin{array}{l}\text { Steibel } \\
2520\end{array}$ \\
\hline 1 & 0.01 & Philibertia gilliesii Hook. \& Arn. (Apocynaceae) & $\begin{array}{l}\text { Enredadera } \\
\text { del avestruz }\end{array}$ & Muiño 84 \\
\hline 1 & 0.01 & Prosopis flexuosa DC. var. flexuosa (Fabaceae) & Algarrobo & Muiño 133 \\
\hline 1 & 0.01 & $\begin{array}{l}\text { Rhodophiala mendocina Ravenna (Phil.) Ravenna } \\
\text { (Amarillydaceae) }\end{array}$ & $\begin{array}{l}\text { Cebolla } \\
\text { del zorro }\end{array}$ & Muiño 74 \\
\hline 1 & 0.01 & Solanum elaeagnifolium Cav. (Solanaceae) & Quillo & Muiño 165 \\
\hline 1 & 0.01 & Suaeda divaricata Moq. (Amaranthaceae) & Vidriera & Muiño 89 \\
\hline & & & & \\
\hline
\end{tabular}

es and plants: tupe (P. urvilleanum), flechilla fina (Nassella tenuis (Phil.) Barkworth), cebadilla (Bromus catharticus Vahl var. rupestris (Speg.) Planchuelo \& P.M. Peterson), pasto de invierno (Schismus barbatus (L.) Thell.), pasto de hoja (Bothriochloa springfieldii (Gould) Parodi), flechilla blanca (Jarava ichu Ruíz \& Pav.), té pampa (Thelesperma megapotamicum (Spreng.) Kuntze), alfilerillo (Erodium cicutarium (L.) L'Hér. ex Aiton) and gramilla (Eragrostis mexicana (Hornem.) Link ssp. virescens (J. Presl.) S.D. Koch \& Sanchéz Vega), all of which were preferred by cattle and sheep. Horses prefer hard grasses like coirón (Pappostipa vaginata (Phil.) Romasch.), flechilla gruesa (A. mendocina) and other shrubs and bushes like Ilaollín (Lycium chilense Miers ex Bertero), tomillo (A. seriphioides), retamilla (Prosopidastrum striatum (Benth.) R. A. Palacios \& Hoc), yerba de oveja (Baccharis gilliesii A. Gray) and molle (Schinus johnstonii F.A. Barkley).

According to the farmers of the area, the characteristics of the best foraging species are related with their capacity for "fattening" the animal and with their palatability, while the plant's volume is not really taken into account. This can be observed in plants like unquillo ( $P$. lanuginosa) which, despite growing in very sparse clumps and having little volume, is locally considered to be one of the most valuable grasses in the area.

In addition to the aforementioned plants, sheep have a particular preference for certain herbaceous species like yerba del pollo (Gomphrena mendocina (Phil.) R.E. Fr.), peludilla (Plantago patagonica Jacq.), yerba de la perdiz (Margyricarpus pinnatus (Lam.) Kuntze), and yerba de oveja (B. gilliesii). Other plants occasionally consumed are blanquilla (Hyalis argentea D. Don ex Hook. \& Arn.), tomillo macho (J. seriphioides) and the inflorescences of melosa (Grindelia chiloensis (Cornel.) Cabrera).

Plants identified as being important in the diet of goats were mainly bushes such as jarilla ( $L$. divaricata), molle (S. johnstonii), alpataco (Prosopis flexuosa DC. var. depressa F.A. Roig), piquillín (Condalia microphylla Cav.), Ilaollín (L. chilense), ala (Monttea aphylla (Miers) Benth. \& Hook. f.), jarillilla (Gochnatia glutinosa (D. Don) D. Don ex Hook. \& Arn.), solupe frutero (Ephedra ochreata Miers), zampa (Atriplex lampa (Moq.) Gillies ex Small), and other species, but in a lower proportion. 


\section{Muiño - Ethnobotanical Study of the Rural Population of the West of the Pampa Plain (Argentina)}

Table 1 indicates the foraging species for all types of livestock. Based on the perception of the informants, foraging importance (IF) is expressed as follows:

$\mathrm{IF}=\mathrm{Is} / \mathrm{N}$

where $I$ is the number of times the species s was cited and $\mathrm{N}$ is the total number of events or interviews. Poaceae and Asteraceae were the most important families based on the number of foraging species, followed by Verbenaceae, Solanaceae, Fabaceae. Others are less well represented in the total number of plants.

Local knowledge on foraging resources not only includes species with good palatability and nutritional characteristics but also plants whose abundance hinders the presence of other good quality forage. A significant increase in these species is considered to be a sign that the pastures have been overloaded with cattle. Within this category the locals identified melosa (G. chiloensis) and tomillo macho (J. seriphioides), both species that are rejected by animals and whose reproductive success makes them invasive species.

\section{Toxic plants or plants with adverse effects on livestock}

Table 2 shows the list of poisonous species or those with adverse effects. The most frequently named toxic plant was tabaco cimarrón (Nicotiana noctiflora Hook.). This plant is only eaten by hungry animals during periods of scarce forage, or by animals from other areas.

Sandilleja (Cucumis anguria L.) was identified as causing intoxications in goats and when ingested in great quantities can be fatal. When eaten in low quantities insufficient to cause toxic effects, it lends the animals' meat and milk a bad taste.

Other plant species may cause losses in sheep, mainly lambs, but not as a result of toxicity. This is the case of some flechilla grasses with hard florets, such as Jarava neaei and $N$. tenuis. These grass florets first pierce the animal's wool and then its skin, causing injuries that can eventually become infected and lead to death.

Some toxic effects are related to the phenological stage of the plant and climatic variations. Unco (Sporobolus rigens (Trin.) E. Desv.) is a plant that can cause intoxications when eaten after an intense resprouting. In other cases, periods of great rainfall generate appropriate conditions for a large-scale establishment of toxic species which would otherwise go unnoticed by the animals. One of these plants is pechuguilla (Euphorbia collina Phil.) that causes severe diarrhoea. The outcome of this intoxication may be fatal, depending on the level of ingestion. The biological activity and toxicity of some of the species recorded in this study have also been previously documented (Bedotti et al. 2002, Sequeiros et al. 2003).

Other cases of intoxication can occur during very rainy springs that lead to intense resprouting and generate appropriate conditions for fungal attacks on plants. This season often brings a particular form of horse constipation, locally known as torozón, caused by the animals grazing intensely on the tender forage of plants such as Ilaollín (L. chilense).

\section{Veterinary treatments}

Problems requiring local treatment are mainly related to inflammatory processes of diverse etiology. These include skin infections, burns, local irritations, etc., all of which are locally known as pasmos.

Calves and foals that will not be used in breeding are branded and castrated at the beginning of autumn. This task is performed under a waning moon as the local tradition considers that it conveys less risk and damage to the animals. In this regard, plants used to reduce inflammation and as disinfectants are jarilla ( $L$. divaricata), bejuco (Eupatorium patens D. Don ex Hook. \& Arn. var. patens) and pichana (Baccharis spartioides (Hook. \& Arn.) Remy). They can be applied directly as poultices made by crushing the aerial parts of the plants or by washing the affected area with lukewarm decoctions. These decoctions are locally known as waters (aguas), hence the names jarilla

Table 2. Six toxic species or species with adverse effects identified by the perception of interviewees (number of quotes) in the western half of Chicalcó department, in the northwest of the province of La Pampa, Argentina.

\begin{tabular}{|c|l|l|l|}
\hline $\begin{array}{c}\text { No. of } \\
\text { quotes }\end{array}$ & Species & Common name & Collection number \\
\hline 6 & Nicotiana noctiflora Hook. (Solanaceae) & Tabaco cimarrón & Muiño 91 \\
\hline 4 & Cucumis anguria L. (Cucurbitaceae) & Sandilleja & Muiño \& Arenas 32 \\
\hline 2 & Sporobolus rigens (Trin.) E. Desv. (Poaceae) & Unco & Muiño 69 \\
\hline 1 & Euphorbia collina Phil. (Euphorbiaceae) & Pechuguilla & Muiño 92 \\
\hline 1 & Jarava neaei (Nees ex Steud.) Peñailillo (Poaceae) & Flechilla & Muiño 2 \\
\hline 1 & Nassella tenuis (Phil.) Barkworth (Poaceae) & Flechilla fina & Muiño 151 \\
\hline
\end{tabular}


or bejuco water. Tomillo ( $A$. seriphioides) is also used to prevent skin irritations by placing two twigs in the shape of a cross between the saddle girth and the animal's skin, a therapeutic treatment with an evident religious metaphorical meaning. The magic and religious therapies include curing by word (curas de palabra) and curing by the animal's footprints (curas por el rastro).

Retention of the placenta is a common problem in animal births. In these cases a concentrated decoction of the stems and leaves of jarilla ( $L$. divaricata) is commonly used as an oral oxytoxic; a decoction of jarillilla (G. glutinosa) is also used, but less frequently.

The parasitoses requiring most primary attention are myiases, including bicheras (mites), horse bots and goat horn flies. Bicheras, caused by the larvae of Cochliomya flies, are treated with jarilla ( $L$. divaricata) and bejuco (E. patens). This treatment consists in applying crushed leaves or a decoction of them on the area, or mixing the latter with other liquids like mineral engine oil or other oily products. These preparations are applied directly onto the wound, covered with cow dung, and then bandaged. A therapeutic variation against myiasis is the use of necklaces made with bejuco ( $E$. patens) branches that are hung around the neck of affected animals until the parasites disappear completely. In these cases, the treatment probably acts as an insect repellent.

Bejuco (E. patens) is also used for treating bot flies (Gasterophilus sp.) and horn flies (Hematobia irritans L.), but in this case it is administered orally. This preparation is also used to treat horses suffering from different gastrointestinal diseases. The treatment for bot flies also includes oral administration of milk with garlic (Allium sativum L.), or diluting bleach in the watering trough.

Mal seco is another disease affecting horses in the area. Clinically identified as equine streptococcal adenitis, it is a bacterial disease caused by the Streptococcus equi that is generally fatal, although in some cases it has a favorable outcome (Gatti Assandri 2007). The horse's chest is massaged with animal fat to speed the infection process and obtain profuse suppuration. This can also be caused by making an incision in the affected region. The wound is then disinfected with a decoction of jarilla (L. divaricata).

Wheat flour mixed with cold water is fed to calves to control diarrhoea, which is also treated with ajenjo (Artemisia absinthium L.) or wormwood water. A concentrated decoction of tamarindo (Tamarix ramosissima Ledeb.) branches is used for diarrhoea in kid goats. All these treatments are administered orally.

Snakebites are an important cause of accidents in herds. When they happen, a decoction of tobacco (Nicotiana tabacum L.) and garlic ( $A$. sativum), or simply tobacco with oil, is applied on the wounds.

The importance of the species for veterinary use is expressed as the number of times they were cited (Table 3).

\section{Rural constructions and tools for livestock}

The use of plants in livestock facilities mainly involves building fences. The posts used for building corrals and fencing the perimeter of the farm are made from caldén

Table 3. Ten species for veterinary use identified by interviewees (number of quotes) in the western half of Chicalcó department, in the northwest of the province of La Pampa, Argentina.

\begin{tabular}{|c|l|l|l|}
\hline $\begin{array}{c}\text { No of } \\
\text { quotes }\end{array}$ & Species & Collection number & Common name \\
\hline 24 & Larrea divaricata Cav. (Zygophyllaceae) & Muiño \& Arenas 38 & Jarilla \\
\hline 12 & $\begin{array}{l}\text { Eupatorium patens D.Don ex Hook. \& Arn. } \\
\text { var. patens (Asteraceae) }\end{array}$ & Mejuco \\
\hline 2 & Allium sativum L. (Alliaceae) & note 1 & Ajo \\
\hline 2 & Nicotiana tabacum L. (Solanaceae) & note 1 & Tabaco \\
\hline 1 & Acantholippia seriphioides (A. Gray) Moldenke (Verbenaceae) & Muiño 119 & Tomillo \\
\hline 1 & Artemisia absinthium L. (Asteraceae) & Muiño \& Rojas 271 & Ajenjo \\
\hline 1 & $\begin{array}{l}\text { Baccharis spartioides (Hook. \& Arn. ex DC.) J. Rémy. } \\
\text { (Asteraceae) }\end{array}$ & Muiño 11 & Pichana \\
\hline 1 & $\begin{array}{l}\text { Gochnatia glutinosa (D. Don) D. Don ex Hook. \& Arn. } \\
\text { (Asteraceae) }\end{array}$ & Muiño 10 & Jarillilla \\
\hline 1 & Tamarix ramosissima Ledeb. (Tamaricaceae) & Muiño 104 & Tamarindo \\
\hline 1 & Triticum aestivum L. (Poaceae) & note 1 & Trigo \\
\hline
\end{tabular}

1. Purchased commercially. 


\section{Muiño - Ethnobotanical Study of the Rural Population of the West of the Pampa Plain (Argentina)}

(Prosopis caldenia Burkart) or algarrobo ( $P$. flexuosa var flexuosa), although the latter is preferred because of its durability. The wattle, and sometimes the posts themselves, is usually made of eucaliptos (Eucalyptus camaldulensis Dehnh., Eucalyptus tereticornis Sm.), which is readily available on the market, or acacia (Robinia pseudoacacia L.). However, it is common to find fences with wattle of local shrubs like jarilla (L. divaricata).

Fence openings consist of gates or tranquerones, an adaptation of a section of the wire fencing that allows enclosures to be opened or closed. Gates and other facilities such as cattle squeeze chutes, loading chutes, headgates and others, are purchased on the market, and are made of hardwood from northern Argentina, usually curupay (Anadenanthera colubrina (Vell.) Brenan var. cebil (Griseb.) Reis) or anchico colorado (Parapiptadenia rigida (Benth.) Brenan). Likewise, the wattle and posts that are purchased are also made of wood alien to the area, such as urundel (Astronium urundeuva (Allemão) Engl.), grapia (Apuleia leiocarpa (Vogel) J.F. Macbr.), itín (Prosopis kuntzei Harms ex Kuntze), quebracho colorado (Schinopsis lorentzii (Griseb.) Engl.) and eucaliptos (E. camaldulensis, E. tereticornis).

Traditional water supply systems like leather balls and buckets call for the use of resistant wood in their support structure. The posts used in these cases are made from native trees like algarrobo ( $P$. flexuosa var. flexuosa) or trees grown in the puestos such as olmos (Ulmus spp.) or acacia (R. pseudoacacia).

The corrals for enclosing goats can be made of different materials, but the fences are traditionally of jarilla $(L$. divaricata) and solupe (Neosparton aphyllum (Gillies \& Hook.) Kuntze), which are held up and reinforced with posts made from acacias (R. pseudoacacia), algarrobo ( $P$. flexuosa var. flexuosa), or piquillín (C. microphylla). Within these corrals there is generally another smaller enclosure made of different materials that is used to hold kid goats during the production season. Modern corrals are made of wooden planks obtained from the outer cuttings of álamo trunks (Populus nigra L.), a species grown extensively in the irrigated areas of neighboring provinces.

Local trees used for making tool handles are, in order of preference, chañar (Geoffroea decorticans (Gillies ex Hook. \& Arn.) Burkart), alpataco ( $P$. flexuosa var. depressa), algarrobo ( $P$. flexuosa var. flexuosa), acacia $(R$. pseudoacacia), olmos (UImus spp.), and jarilla (L. divaricata). Before being used, the ends of the handles are superficially burnt to prevent the wood from cracking later.

Due to local abundance, jarilla has a great variety of uses. In addition to the above, it is also used to make bradawls, roasting spits, sheave axles, wattle for drying cheese, and brooms, although pichana (B. spartioides) branches are preferred for the latter whenever they are available in the area.

Leatherwork is intimately related to livestock activities and plants are also used for this type of handicraft. The bars of packsaddles are filled with blanquilla $(H$. argentea), melosa (G. chiloensis) or unco (S. rigens). Certain plants are also used for dying: yerba mate (Ilex paraguariensis A. St.-Hil.) is used to give the leather used for making ropes different shades of grey. The dye is made by collecting the leaves left over from the traditional infusion called mate in a tin container. The oxidation produced when this deposit is exposed to the air gives it a black color that after a few months can be used for staining leather. No plants are used in the curing of leather; mineral compounds like salt and alum are used instead. Table 4 shows the importance of the species in rural constructions based on the number of times they were cited.

\section{Discussion}

As in other communities of the Monte region, the economy of the inhabitants of the west Pampa is based on livestock. However, these people do not maintain the transhumance practices of other communities in the region (Ladio \& Lozada 2008). One of the prime reasons influencing sedentary animal farming probably has a cultural origin. The farmers in this study descend from colonizers that established small settlements and military forts at the end of the 19th century. These settlements were located close to natural sources of water where sedentary grazing could be carried out in the open grasslands. The settlers of the areas near the Andes were those who adopted, and still maintain, transhumance practices, using the higher mountain pastures called veranadas in summer and migrating to lower pastures in winter. However, the flat landscape of the Pampa does not favour this practice. This, and the scarcity of water sources, might have been sufficient reason to adopt a sedentary animal farming activity instead of transhumance.

Of the total number of species cited in this study, the use of wild plants for livestock (60 species) comprises $20 \%$ of the total estimated flora of the study area (294 species), according to information obtained from the database of the SRFA herbarium and the vegetation surveys of the area (INTA, Gob. de La Pampa, UNLPam 1980, Troiani et al. 1994). This percentage of use is particularly important if the lower specific relative abundance in the area that is characteristic of arid ecosystems is taken into account.

Although most foraging species belong to the Poaceae family, $75 \%$ of the resources quoted within this category of use are dicotyledons. This is consistent with the two predominant types of livestock in the area since bovines feed primarily on the herbaceous strata composed mostly of grasses, while goats feed on the shrub strata, which mainly comprises woody dicotyledons. 
Table 4. Sixteen taxa ( 15 species with two varieties of $P$. flexuosa) used for rural constructions identified by interviewees (number of quotes) in the western half of Chicalcó department, in the northwest of the province of La Pampa, Argentina.

\begin{tabular}{|c|l|l|l|}
\hline $\begin{array}{c}\text { Number } \\
\text { of quotes }\end{array}$ & Species & $\begin{array}{l}\text { Collection } \\
\text { number }\end{array}$ & $\begin{array}{l}\text { Common } \\
\text { name }\end{array}$ \\
\hline 21 & Larrea divaricata Cav. (Zygophyllaceae) & $\begin{array}{l}\text { Muiño \& } \\
\text { Arenas 38 }\end{array}$ & Jarilla \\
\hline 17 & Prosopis flexuosa DC. var. flexuosa (Fabaceae) & Muiño 133 & Algarrobo \\
\hline 8 & $\begin{array}{l}\text { Baccharis spartioides (Hook. \& Arn. ex DC.) J. Rémy. } \\
\text { (Asteraceae) }\end{array}$ & Muiño 11 & Pichana \\
\hline 8 & Prosopis caldenia Burkart (Fabaceae) & Muiño 134 & Caldén \\
\hline 7 & $\begin{array}{l}\text { Geoffroea decorticans (Gillies ex Hook. \& Arn.) Burkart } \\
\text { (Fabaceae) }\end{array}$ & Muiño 161 & Chañar \\
\hline 6 & Populus nigra L. (Salicaceae) & Muiño 272 & Álamo \\
\hline 4 & Prosopis flexuosa DC. var. depressa F.A. Roig (Fabaceae) & Muiño 102 & Alpataco \\
\hline 3 & Robinia pseudoacacia L. (Fabaceae) & Muiño 162 & Acacia \\
\hline 2 & Eucalyptus spp. (Myrtaceae) & Muiño 217 & Eucalipto \\
\hline 2 & Ulmus spp. (Ulmaceae) & Muiño 235 & Olmo \\
\hline 1 & Condalia microphylla Cav. (Rhamnaceae) & Muiño 13 & Piquillín \\
\hline 1 & Grindelia chiloensis (Cornel.) Cabrera (Asteraceae) & Muiño 73 & Melosa \\
\hline 1 & Hyalis argentea D. Don ex Hook. \& Arn (Asteraceae) & Muiño 79 & Blanquilla \\
\hline 1 & Ilex paraguariensis A.St.-Hil. var. paraguariensis (Aquifoliaceae) & note 1 & Yerba \\
\hline 1 & Neosparton aphyllum (Gillies \& Hook.) Kuntze (Verbenaceae) & Muiño 114 & Solupe \\
\hline 1 & Sporobolus rigens (Trin.) E. Desv. (Poaceae) & Muiño 69 & Unco \\
\hline
\end{tabular}

1. Purchased commercially.

As observed in other grazing communities, these communities have detailed knowledge of the foraging species present in the area. This experience is dynamic and accumulative, as revealed by certain testimonies concerning the present increased abundance of non-foraging invasive species over those of better foraging quality. This information shows that puesteros are conscious of the changes occurring in the ecosystem as a result of environmental pressures.

The locals' capacity of observation includes all the natural elements in their environment. As a consequence they use empirical forms of management. Evidence for this is the choice of days on which to perform certain activities. For example, calves should be castrated during a waning moon, a period during which they believe there are fewer risks of complications in wounds. The relationship between the choice of the lunar phase and the effectiveness of certain veterinary treatments has previously been observed in other ethnobotanical and anthropological studies of rural communities in Argentina (Jiménez de Pupareli 1984, Scarpa 2000).

Regarding plants that are toxic for cattle, most interviewees recognize the existence of only five species and clearly identify the symptoms caused in the animals. How- ever, cases of intoxication related to N. noctiflora, C. anguria and $E$. collina are highly infrequent.

We also recorded a plant that does not normally produce intoxications, but that can become toxic under certain climatic conditions. Sporobolus rigens is a grass with toxic effects on herbivores when eaten after an intense spring resprouting. The effect has been observed in other grasses and is probably related to metabolic changes that lead to an accumulation of cyanogenic compounds under certain environmental conditions (Gallo 1979).

Regarding medicinal plants for veterinary uses, an equal proportion of native and exotic species, either cultivated or commercially acquired, is used. Nevertheless, the two plants most commonly used for veterinary purposes are native species that are easily obtained due to their abundance. Traditional treatments are mainly applied in first aid cases and less serious acute problems, while commercial veterinary products are preferred for treating diseases of greater risk. These products may be easily obtained from nearby urban centers, but the subsequent impact on the loss of knowledge and use of natural resources is a trend already observed in the use of wild plants (Reyes García et al. 2005). 


\section{Muiño - Ethnobotanical Study of the Rural Population of the West of the Pampa Plain (Argentina)}

Among the plants used for veterinary treatments, oxytoxic, anti-parasitic and disinfectant species stand out. However, a very important ensemble of magical and religious practices that are also common in other rural areas of Argentina is associated with these treatments and calls for elements of animal and mineral origin in addition to plants (Bartolomé 1968, Jiménez de Pupareli 1984). The importance of these beliefs in veterinary therapies is exemplified in the preventative practice for skin irritations in horses in which the invocation of the cross holds evident religious connotations.

It is important to note that throughout the Pampa region the generalized concept of illness is that of an intrusive substance in the organism that must be removed. This concept persists in this study area and is seen in the use of practices that encourage infections to mature and "emerge", practices for expelling internal and external parasites, and poultices and washes for eliminating pasmos.

The design and type of materials that predominate in livestock facilities are those that are available commercially and which are generally made from foreign raw materials. However, they coexist with other typical traditional constructions in the animal farming regions of the country such as the fences used to enclose goats. The diversity of uses given to plants for making tools and rural installations is related to the abundance of species in the area. An example of this is the use of $L$. divaricata. In the case of trees, there is no difference in the diversity of uses between native species like $P$. flexuosa and other exotic species such as $R$. pseudoacacia and $P$. nigra cultivated in peridomestic areas. Within this category, the scarce use of C. microphylla is noticeable when considering the resistance of its wood. Older informants claim that the main reason for this is the dramatic fall in the number of large plants of this species.

\section{Conclusion}

This study presents the results of an investigation that basically consisted in saving traditional knowledge on a sapiential issue in a determined community. Beyond the value of the documentation on the cultural and natural patrimony, the aim of this investigation is to provide a useful tool for the implementation of policies targeting the farmers of the region. In fact, actions developed in arid ecosystems must not only consider the results of studies describing the environment but also the traditional knowledge of the human groups living in them. This will allow for better results in efforts to promote the conservation of biological and cultural diversity.

\section{Literature Cited}

Anderson, D.L., J.A. Del Águila \& A.E. Bernardon. 1970. Las formaciones vegetales en la provincia de San Luis. Revista de Investigaciones Agropecuarias. Instituto Nacional de Tecnología Agropecuaria, Buenos Aires, Argentina. Serie 2, Biología y Producción Vegetal 7(3):153-183.

Bartolomé, L.J. 1968. El pensamiento mítico en la veterinaria folklórica. Runa 11(1-2):71-92.

Barroso, H.D. 2000. Las técnicas de recolección de datos. Pp. 237-267 in Investigación Social. Edited by R. Perez Lalanne. Facultad de Ciencias Sociales. Universidad Nacional de Lomas de Zamora, Buenos Aires.

Bedotti, D., A. Miranda, H. Allende \& H. Troiani. 2002. Primera comunicación sobre la intoxicación por Euphorbia dentata en bovinos de la provincia de La Pampa. Instituto Nacional de Tecnología Agropecuaria. Boletín de Divulgación Técnica 73:117-118.

Boelcke, O. 1957. Comunidades herbáceas del Norte de Patagonia y sus relaciones con la ganadería. Revista de Investigaciones Agrícolas 11(1):5-98.

Bollig, M. \& A. Schulte. 1999. Environmental change and pastoral perceptions: Degradation and indigenous knowledge in two african pastoral communities. Human Ecology 27:493-514.

Borrelli, P. \& G. Oliva. 2001. Editors of Ganadería ovina sustentable en la Patagonia austral. Tecnología de manejo extensivo. Instituto Nacional de Tecnología Agropecuaria, E.E.A. Santa Cruz. Convenio INTA - UNPA - CAP. Río Gallegos, Argentina.

Cabrera, A.L. 1971. Fitogeografía de la República Argentina. Boletín de la Sociedad Argentina de Botánica 14:142.

Casagrande, G.A., G.T. Vergara \& Y. Bellini. 2006. Cartas agroclimáticas actuales de temperaturas, heladas y lluvia de la provincia de La Pampa (Argentina). Revista de la Facultad de Agronomía-Universidad Nacional de La Pampa 17(1/2):15-22.

Cano, E. 1988. Pastizales naturales de La Pampa. Descripción de las especies más importantes. Volume 1. Convenio Asociación Argentina de Consorcios Regionales de Experimentacion Agricola, Provincia de La Pampa.

Cuello, P. 1968. Bases para la ecología del Departamento Chical Có en el extremo oeste pampeano. Ministerio de Economía y Asuntos Agrarios. Gobierno de La Pampa. 
Cuello, P \& A.M. Montone. 1999. Cambio en el tiempo del las especies ganaderas en el espacio árido pampeano. Informe del Departamento de Geografía. Facultad de Ciencias Humanas. Universidad Nacional de La Pampa, Santa Rosa.

Feito, M.C. 2004. Antropología y políticas sociales rurales: Una relación fructífera pero poco reconocida. Revista Interdisciplinaria de Estudios Agrícolas 21:55-76.

Gallo, G.G. 1979. Plantas Tóxicas para el Ganado en el cono sur de América. Editorial Universitaria de Buenos Aires. Buenos Aires.

Gatti Assandri, M. 2007. Adenitis equina. www.produccion-animal.com.ar/produccion_equinos/produccion_ equina_en_general/52-adenitis.pdf

Golluscio, R.A., V.A. Deregibus \& J.M. Paruelo. 1998. Sustainability and range management in the Patagonian steppes. Ecología Austral 8:265-284.

Gras, C. \& P. Barbetta. 2004. Trabajo y organización laboral en las pequeñas y medianas explotaciones de la región pampeana. Revista Interdisciplinaria de Estudios Agrarios 21:33-53.

Grünwaldt, E. A. Vich \& A. Pedrani. 1992. Manejo de cuencas. Interrelación de la ganadería con la vegetación y el suelo. Multequina 1:47-51.

Guber, R. 2001. La Etnografía. Método, campo y reflexividad. Norma, Bogotá.

Guevara, J.C., O.R. Estévez \& E.R. Torres. 1996. Utilization of the rain - use efficiency factor for determining potential cattle production in the Mendoza plain, Argentina. Journal of Arid Environments 33:347-353.

INDEC. 2001. Instituto Nacional de Estadística y Censos. Censo nacional de población, hogares y vivienda 2001. Serie 2. Resultados generales. No 11 Province of La Pampa.

INTA, Gob. de la Pampa UNLPam. 1980. Inventario Integrado de los Recursos Naturales de la Provincia de La Pampa. Instituto Nacional de Tecnología Agropecuaria, Santa Rosa, Argentina.

Jiménez de Pupareli, D. 1984. Aspectos tradicionales de la ganadería. Pp. 77-89 in Cultura Tradicional del área del Paraná Medio. Edited by F.F.G. Bracht. Instituto Nacional de Antropología, Buenos Aires.

Ladio, A.H. \& M. Lozada. 2004. Summer cattle transhumance and wild edible plant gathering in a Mapuche community of Northwestern Patagonia. Human Ecology 32(2):225-240.
Ladio, A.H. \& M. Lozada. 2008. Human ecology, ethnobotany and traditional practices in rural populations inhabiting the Monte region: Resilience and ecological knowledge. Journal of Arid Environments 73:222-227.

Martin, G.J. 2001. Etnobotánica. Manual de métodos. Nordan - Comunidad. Montevideo, Uruguay.

Martínez Carretero, E. 2004. La provincia fitogeográfica de la Payunia. Boletín de la Sociedad Argentina de Botánica 39(3-4):195-226.

Montes, L. \& G.E. Oliva. 1995. Editors of Patagonia. Actas del Taller Internacional sobre Recursos Fitogenéticos, Desertificación y Uso Sustentable. Instituto Nacional de Tecnología Agropecuaria, - Centro Regional Patagonia Sur - E.E.A. Santa Cruz, Río Gallegos, Argentina.

Ojeda, R.A., C.M. Campos, J.M. Gonnet, C.E. Borghi \& V.G. Roig. 1998. The MaB Reserve of Nacuñán, Argentina: Its role in understanding the Monte desert biome. Journal of Arid Environments 39:299-313.

Poduje, M.I. 2000. Viviendas tradicionales en la provincia de La Pampa. Departamento de Investigaciones Culturales, Gobierno de la provincia de La Pampa. Santa Rosa, Argentina.

Scarpa, G.F. 2000. Plants employed in traditional veterinary medicine by the criollos of the Northwestern Argentine Chaco. Darwiniana 38(3-4):253-265.

Scarpa, G.F. 2007. Etnobotánica de los Criollos del oeste de Formosa: Conocimiento tradicional, valoración y manejo de las plantas forrajeras. Kurtziana 33(1):153-174.

Reyes-García, V., V. Valdez, T. Huanca, W. Leonard \& D. Wilkie. 2005. Knowledge and consumption of wild plants: A comparative study in two Tsimane villages in the Bolivian Amazon. Ethnobotany Research \& Applications 3: 201-207.

Sequeiros, C., L.M.I. López, N.O. Caffini \& C.L. Natalucci. 2003. Proteolytic activity in some Patagonian plants from Argentina. Fitoterapia 74:570-577.

Torres, G.F. \& M.E. Santoni. 2003. Algunos aspectos de la veterinaria folklórica del departamento La Caldera (Salta, Argentina). Kallawaya Nueva Serie 10/11. www.antropomédica.com.ar/Kalla_10.htm

Troiani, H., P. Steibel, G. Alfonso \& A. Prina. 1994. Catálogo de la Flora de la Provincia de La Pampa (Argentina). Actas VI Congreso Latinoamericano de Botánica. Mar del Plata, Argentina. 


\section{Pampa Plain (Argentina)}

Zuluaga, J.A. 1973. La ganadería en Mendoza. Deserta 4. Pp 215-231 in Contribuciones del Instituto Argentino de Investigaciones de las Zonas Áridas. Mendoza. 
